\title{
AN UNPAID DEBT TO SOCIETY: HOW 'PUNISHMENT DEBT' AFFECTS REINTEGRATION AND DESISTANCE FROM CRIME IN NORWAY
}

\author{
JOHN TODD-KVAM
}

\begin{abstract}
The Scandinavian exceptionalism literature has highlighted the relatively progressive and rehabilitative nature of imprisonment in Norway, with the Norwegian Correctional Services taking the view that those convicted of crimes have paid their debt to society at the end of their sentence. However, other parts of the Norwegian state take a more stringent view, imposing and enforcing significant and persistent debts on offenders. This article, based on official documents and interviews with Norwegian desisters and probation caseworkers, analyses how living with debt poses a major challenge for reintegration and desistance. Referred to informally as 'punishment debt', this pervasive but less visible aspect of Norwegian penality demonstrates the need to broaden the penal exceptionalism research agenda beyond the confines of the prison.
\end{abstract}

\section{Introduction: debt and offending in Norway}

A major challenge facing people subject to punishment is dealing with limited economic capital. As this article will underline, this challenge is relevant for those in the relatively affluent welfare states of Scandinavia as well as more overtly exclusionary (Cavadino and Dignan 2005) political economies. Whilst debt in some circumstances can be useful in generating capital (whether on the individual level of micro-finance, or states borrowing to invest), for many it is a trap to be feared and an unproductive drain on economic capital. The Scandinavian exceptionalism literature has discussed the relatively progressive and rehabilitative nature of imprisonment in Norway, with the Norwegian Correctional Services taking the view that those convicted of crimes have paid their debt to society at the end of their sentence (Norwegian Ministry of Justice and the Police 2008). However, courts and other parts of the Norwegian state take a more stringent view, imposing and enforcing significant and persistent debt. In 2017, 131 people owed over 1 million Norwegian Kroner (approximately $£ 930,000$ ) to the state in unpaid criminal compensation claims (Boyesen 2017). In the same year, the state recorded an income of 3.2 billion kroner (approximately $£ 300$ million) in "fines, penalties and forfeits" (Statistics Norway 2018a). Such debt is often labelled 'punishment debt'. This less visible, more retributive form of punishment speaks to a need to broaden our knowledge and understanding of penality in Scandinavia and, by extension, the conditions for reintegration and desistance.

Debates over penal exceptionalism started in this journal by John Pratt (2008a, 2008b) a decade ago have focused in the main on prison, specifically terms (is prison used less in Scandinavia?) and conditions (are Scandinavian prisons more humane?). I contend that we now need to broaden our focus horizontally and vertically. Horizontally to include more emphasis on other forms of sanction ${ }^{1}$ and what happens after imprisonment, and vertically to include more emphasis on lived experiences of punishment and its consequences, since much penal exceptionalism research to date has focused on structures and practices of punishment. This is not to say there has 
been an exclusively narrow focus (see for example Smith and Uglevik 2017, Reiter et al. 2018), rather that further useful insights are to be gained from actively broadening our perspective.

This article aims to contribute along both dimensions by examining how the intertwining of debt and offending affect reintegration and impact on the lives of a number of Norwegian desisters. The article begins with some theoretical framing that draws together overlapping insights from the literatures on penal exceptionalism, pervasive punishment and desistance before providing some detail on methods. The two empirical sections first take a systemic perspective on how reintegration is impacted by so-called 'punishment debt' and second a bottom-up analysis of how debt is experienced as impacting on desistance, both by desisters and probation caseworkers. The article concludes that 'punishment debt' can mean becoming trapped in a state of frozen liminality and raises implications for desistance, penal exceptionalism and penological research more broadly.

\section{Theoretical framing: punishment, liminality and desistance}

Norway is a strong welfare state with significant capacity to intervene in the lives of its population - this much is reasonably well accepted by those who have studied the nature and extent of penal exceptionalism. Where there has been debate, much of it has been about where to position Norway and other Scandinavian/Nordic states (or, dropping down a level of analysis, individual punishing institutions) on a progressivepunitive axis. Smith and Ugelvik (2017b) propose a third way of the "Big Mother penal welfare state model" that helps account for how punishment and welfare coexist, often in a panoptic disciplining of penal subjects aimed at producing rehabilitated citizens. However, this rather intrusive inclusion is not the whole story. As Smith and Ugelvik highlight, Big Mother also employs her capabilities more harshly, with exclusionary practices expressly directed against those seen as too different or difficult. A clear example here is ban-optic discourses and practices directed against non-citizens (Aas 2014; Shammas 2017; XXXX 2018; Ugelvik and Damsa 2017 inter alia). In broadening our perspective beyond the prison, other marginalising — even maloptic (McNeill 2018a) — aspects of punishment come into view. Mass supervision/probation as described by McNeill (ibid) and Phelps (2017) is, though, less prevalent in Norway: few ex-prisoners encounter the probation service and community sentences are comparatively uncommon (Statistics Norway 2018b). However, punishment pervades and persists through people's lives in other ways. Debt surveillance and enforcement is one such way. Another is homelessness, with the report "Released and homeless" suggesting imprisonment often results in homelessness and that for some inmates it is a permanent condition (Dyb et al. 2006: 19-20). So, whilst the concept of liminality (the experience of being neither fully excluded nor fully included) has previously been applied only to prisoners in Norway (Ugelvik 2012), we should consider Maruna's (2011) observation that liminality is relevant not only in rituals of imprisonment, but it also extends, potentially endlessly, across the lives of those receiving criminal sanctions. McNeill (2018a: 10) also highlights endlessness and interminability contributing to an experience of liminality and being "half in and half out of the community and the polity". Whilst originally conceptualized as temporary (Turner 1969/2008), both Maruna and McNeill describe how, when reintegration is hindered, liminality becomes a more lasting status. As 
subsequent sections of this article make clear, debt surveillance and enforcement is a potentially endless hinder to reintegration.

Desistance also involves experiencing liminality (Healy 2010; King 2012, Nugent and Schinkel 2016). Liminality encapsulates how desistance involves more than just avoiding criminal behaviour (termed primary desistance, see Maruna et al. 2004). Desistance also involves changing how one sees oneself, moving away from an identity bound up in criminality towards a more pro-social identity (secondary desistance, ibid.) Importantly, these efforts to change behaviour and identity also need recognition from others, be it family and friends, probation caseworkers or society as a whole (McNeill (2016) terms this tertiary desistance). An extended experience of liminality, or frustrated secondary and tertiary desistance (one could argue that they are two sides of the same coin), risks creating what Halsey et al. (2016) memorably describe as a 'fuck it' moment where desistance derails. Overall, whilst debt has been listed as one of the hurdles that a potential desister needs to overcome (Giordano et al. 2002; McNeill and Maruna 2007; Rex 1999; Richards and Jones 2004; Shapland et al. 2012) ${ }^{2}$, the literature is less forthcoming regarding how debt impacts primary, secondary and tertiary desistance (though see Trotter and Sheehan (2017)) and how it may entrench an experience of liminality.

So even in the penal welfare state we must ask when does punishment end? At the end of the prison sentence? Whilst the Norwegian Correctional Services perceive someone's debt to society as paid once their sentence is over, the experience of being punished and of being trapped in a liminal position in Norwegian society may endure - particularly if one's financial debts to society remain unpaid.

\section{Research Methods}

This article uses data gathered from multiple sources. Norwegian legislation, official documents and websites, and material produced by the Norwegian Red Cross's Network after Imprisonment provide an account of how debt is accumulated, surveiled and enforced (section 4). To develop an understanding of how this debt is experienced by those seeking to desist from crime (section 5), I analyse data from interviews carried out with probation officers $(\mathrm{N}=8)$ and desisters $(\mathrm{N}=9)$. The desisters were purposively sampled from those I got to know during fieldwork at Network after Imprisonment's Network House, described as “Norway's first re-entry centre', where those seeking to move away from crime can access education, training, social activities, help in finding employment, one-to-one contact with a volunteer support contact and debt advice (Svendsen and Lorange n.d.). The organisation aims to "help participants put a life of crime and drugs behind them, identify and use their strengths in a positive way, make new contacts and have positive experiences" (ibid). Based on an understanding of desistance as a fluid process (McNeill et al. 2012: 3), I interviewed people who self-define as being actively engaged in moving away from crime, i.e. those who see themselves as desisting rather than as having desisted. Whilst not a formal inclusion criterion, no interviewee reported recent offending. The sample includes a range of profiles: two interviewees coming to the end of a single long sentence, one having avoided prison but who received other sanctions and the rest (6) having histories of drug use and repeat offending. Those interviewed include men (7) and women (2), people born in Norway (7) and people born elsewhere (2). I also include data from an interview with the leader of the Red Cross 'Debt project', 
an initiative to provide current and former inmates with advice and support in dealing with debt (Eriksrud 2016).

The fieldwork involved helping out with cooking, washing dishes and in various other ways in addition to hanging out, drinking coffee and playing chess. I got to know the regular core of participants working in the café, kitchen or bike workshop well over the course of the year. The fieldwork helped me understand the lived experience of desistance in Norway over time - a useful addition to the one-off nature of the interviews. Those using the Network House to support their journey away from crime repeatedly mentioned debt as a major difficulty and, as such, prompted this article. Also, in getting to know people well I was able to interview some who would have been reluctant to talk to a relative stranger. The detailed data analysed in section 5 is from the semi-structured interviews. Analytical categories were developed inductively from the data material, with close attention paid to what mattered to participants and what meanings they attributed (analogous to interpretive phenomenological analysis, see Smith and Osborn 2007). Emergent themes were then revised in light of the theoretical framework above and the extant literature on debt and offending set out below.

The study's limitations flow in the main from the nature of the sample. The desisters interviewed are all from one third sector organisation: their way of working and engaging with people may shape the way respondents discuss their desistance. This, combined with the small sample size, prevents empirical generalisation, though this is not what I aim for here. Interviewing only those actively engaged in desistance precludes learning from those whose desistance has recently derailed: their experience of debt might be different (e.g. it weighs even heavier and contributed directly to derailment, or alternatively is less problematic if they have no plans to repay it). This study could therefore be complemented by using the Norwegian state's extensive (one might say panoptic) register data to explore the link between 'punishment debt' and reoffending.

\section{Reintegration restricted: how 'punishment debt' is accumulated and enforced}

The Norwegian state places considerable emphasis on rehabilitation and reintegration in strategy documents (Departementene 2017; Norwegian Ministry of Justice and the Police 2008) and correctional service practice (although budget cuts have created difficulties for delivering rehabilitatory practices and programmes (Anderson and Gröning 2017; XXXX forthcoming)). Housing, education and training, employment and benefits, social support, health services and financial advice are set out as key elements in returning prisoners to society (Justis- og Politidepartement 2008: 176). This final category includes debt advice. Debt has been shown to impact reintegration in other jurisdictions: Aaltonen et al. (2016) use Finnish register data to determine that debt and crime are strongly associated, with increased offending during periods of debt enforcement. The authors also suggest that exacerbation of debt is an important aspect of the cumulative disadvantage (Sampson and Laub 1997) associated with criminal sanctions. Harris et al. (2010) similarly describe how monetary sanctions in the U.S. reproduce inequality through long term and substantial "legal debt". This accumulates disadvantage by reducing family income, limiting access to opportunities (e.g. housing, credit, transportation and employment) and increasing the likelihood of further entanglement with the criminal justice system (p. 
1756). Overall, the authors note that this legal debt "may encourage antisocial rather than prosocial outcomes" (p. 1792). See also Levingston and Turetsky (2007), Bannon et al. (2010) and Evans (2014). Martire et al. (2011) emphasise the strain unmanageable debt places upon those re-entering the community from prison and highlight the paucity of research on the fine-related or general debt burden of offenders (p. 261).

Those with criminal convictions in Norway may have debt to the state, to private creditors and/or to others involved in offending. In a study of prisoners' living conditions, Statistics Norway found $81 \%$ of prisoners had debt, with $32 \%$ having consumer loans, $37 \%$ having debt from being sentenced to pay compensation, $26 \%$ having unpaid fines and 17\% with debt to private persons (including illegal debt such as drug debts) (Revold 2015: 29). That nearly two in five inmates sampled had compensation-related debt is significant, and it is this and other forms of debt to the state that are unusual in scale and permanency. Indeed, in 2017 the state recorded a 3.2 billion Norwegian kroner (NOK) $(£ 300 \mathrm{~m})$ income from fines, compensation and confiscation payments (Statistics Norway 2018a). Whilst little research exists on debt and crime in Norway (though see Andvig et al. (2019) on the importance of debt advice and achieving "economic freedom"), Annette Olesen has written extensively about it in the Danish context (Olesen 2013, 2016; Olesen and Storgaard 2016; Olesen 2017). Olesen sheds light on one aspect of the Danish system more punitive than progressive: offenders are held liable for their legal costs. Whilst less prevalent in Norway, Olesen identifies factors relevant beyond Denmark. For example, Olesen (2016: 699) highlights how imposition of legal costs and thereby significant debt on ex-prisoners extends "informal punishment" and erects barriers for reintegration. Similar to Harris et al. above, Olesen shows how access to housing, credit, transportation and savings are limited and motivation to find employment or start education is undermined. Olesen also argues that legal costs and debt "may encourage antisocial rather than pro-social behaviour." (ibid: 698). This is partly because exprisoners are pushed towards an alternative lifestyle outside the mainstream, avoiding reporting income, bank accounts and other tracks detectable by the state (Olesen 2017: 284). In addition, many ex-prisoners saw the legal costs as unfair and an extra punishment (ibid: 277), something familiar for Norwegian ex-prisoners too. Indeed, policies and practices regarding 'punishment debt' hinder reintegration and are in effect a hidden, pervasive extension of punishment and surveillance that extends far beyond the prison.

The link between debt and mental health issues is also significant. One recent international meta-review found strong relationships between personal unsecured debt and "overall mental disorder, depression, suicide completion or attempt, problem drinking, drug dependence, neurotic disorders and psychotic disorders" (Richardson et al. 2013: 1154; see also Jenkins et al. 2008). These issues are of course also prevalent amongst prisoners, including in Norway (Amundsen 2006; Revold 2015), and are often identified as challenges for reintegration and desistance. Household debt (particularly long-term debt) negatively impacts both mental and physical health (Clayton et al. 2015; Sweet et al. 2013). Selenko and Batinic (2011) found perceived financial strain was a strong predictor of distress and, interestingly from a desistance perspective, that belief in self-efficacy and access to a collective purpose moderated financial strain's mental health impact. As section five will make clear, the maloptic 
tendencies of debt surveillance and enforcement can be somewhat ameliorated via positive relationships and a sense of making progress.

\subsection{Sources of debt: compensation, fines and confiscation}

At first glance, the Norwegian compensation scheme might appear similar to that in England and Wales. The maximum compensation payment to a victim of violence is just over 5.8 million NOK (approximately £540,000) (Kontoret for

Voldsoffererstatning 2014) - this is the same order of magnitude as the maximum of $£ 500,000$ in England and Wales (Ministry of Justice 2012: 13). However, there is a key difference: in Norway the state demands repayment of this compensation from the offender (Kontoret for Voldsoffererstatning n.d.), whereas in England and Wales the taxpayer ultimately foots the bill (Miers 2014: 155) ${ }^{3}$. Criminal courts may also award compensation even if the defendant is acquitted (Johnsen 2001) and victims may seek compensation directly from the compensation authority if no conviction is reached (Kontoret for Voldsoffererstatning 2018). In addition to individual victims, organisations, insurance companies and others awarded compensation can reclaim it from those judged responsible via the state debt collection agency. This is a departure from O'Malley's (2011: 546) observation that damages are usually paid by insurers. For example, the Norwegian state broadcaster NRK related how a 24-year old man had served a 3.5-year sentence for arson against a church (Boyesen 2017). On release, he received an invoice in the post for 34.4 million NOK ( $£ 3.2$ million) with a 14-day payment deadline: the church's insurance company wished to reclaim its costs. The state now deducts $1,100 \mathrm{NOK}(£ 100)$ each month from his disability benefits, which he described as a "sort of life sentence."

In 2016 there were 276,655 fines awarded in Norway, the vast majority for traffic offences (Statistics Norway 2018b). Fines accompanied around half of all conditional and one in four unconditional prison sentences; almost 250 of those receiving both a fine and unconditional prison sentence were fined over 50,000NOK (ibid). In addition to fines and compensation/redress payments, Norwegian courts also order confiscation of profits from criminal acts. In serious cases (e.g. organized crime, drug trafficking) the court may invert the burden of proof, ordering "extended confiscation", whereby all assets are confiscated unless it is demonstrated they were obtained legally (Iversen 2008).

\subsection{State debt collection}

In practice, debts to the state are pursued both centrally (often by the Norwegian National Collection Agency (SISMO)) and locally (by tax collectors and bailiffs in each municipality). In 2017 SISMO collected 1.4 billion NOK (approximately $£ 130$ million) in "fines, confiscation and other criminal claims" (Skatteetaten 2018: 71). SISMO had on its books 968 million the (approximately $£ 91$ million) of owed criminal compensation claims, with amounts varying from 100NOK to 80 million NOK. Over 130 people owed at least 1 million NOK (Boyesen 2017). The following is a translation from the National Collection Agency's website regarding how they keep track of people who owe them compensation payments:

The National Collections Agency has a comprehensive automatic system that searches every single night in various registers to find out if there is anything of value that we can collect. Once we find something, the collection process starts. [bold in original text] We collect data from banks, grant-giving authorities, copyright organisations, the central securities register, registers of small boats and motorcars, 
property registers, ship registers, aircraft registers, housing associations and the Register of Business Enterprises. In addition, we access the State Register of Employers and Employees and the State Welfare registers. We also have extensive electronic communications with many institutions (Statens innkrevingssentral 2018).

This paragraph illustrates the pervasive ability of SISMO to surveil those who owe compensation. Those who fall within SISMO's remit receive an invoice in the post with a 14-day payment deadline. SISMO is empowered to seize assets and make wage deductions should voluntary payment (either in full or via monthly repayments) not be forthcoming. The state also charges interest should repayment be delayed.

\subsection{Debt settlement}

It is possible to seek a combined debt settlement with both state and private creditors. This settlement involves a period of usually 5 years of all surplus resources over an agreed subsistence sum being put towards debt repayment, after which all remaining debt is forgiven. This is quite literally a once in a lifetime opportunity with strict criteria and a demanding application process. Moreover, 'punishment debt' is considered much more strictly than debt to private creditors. According to Norwegian law, debt accrued as a result of a criminal act must be fully repaid, though with possible exceptions for debt more than three years old or if there is special case for resocialisation, and consideration of the person owed the compensation is not a deciding factor (Gjeldsordningsloven 1992). In making these judgements, special weight is given to the nature of the offence committed.

\subsection{Debt advice}

In principle, both inmates in Norwegian prisons and those in the community are entitled to debt advice delivered by the state welfare agency, with the Norwegian Correctional Services responsible for facilitating cooperation for those in prison. However, both levels of expertise and welfare agency presence vary across the prison estate, with some inmates thus having difficulty accessing relevant services (Hansen 2017).

Overall, the policies and practices of debt surveillance and enforcement create both practical consequences with respect to lack of economic capital (e.g. wage deductions, forced sale of assets), but also carry symbolic and psychological impact. The following section will explore how this is experienced.

\section{Experiences of debt: desisters and probation case-workers}

The interview data suggests four particularly negative aspects of living with 'punishment debt'. These are the fear of getting started in dealing with debt, a sense of unfairness and double punishment, undermining job motivation and a feeling of inescapability. However, a number of informants described some sense of progress, with the prospect of a debt settlement providing a goal towards which to work.

Indeed, one of the most impressive things about getting to know those seeking to turn their lives around is their persistence (to use the word in a positive sense for once) in the face of a wide range of obstacles - with debt being perceived as one of the most demanding. 


\subsection{Fear of getting started in dealing with debt}

It is common for those involved in offending to lose control over their finances completely, including how much is owed to a wide range of creditors (both official and unofficial). As the debt project leader explained,

Very many of those I meet have like the whole catalogue of debt [...] Fines, restitution, compensation [...] And, if people never see way out of a problem, then there is often no motivation to sort out their lives in other areas either.

One desister described this sense of bills and letters piling up as follows:

Anna: I have been there where I have thrown bills in the bin. Like unopened. I have been there and not answered the phone when creditors ring and so on. Like you don't have any answer to give them.

Anna has, as she sees it, less debt than many others - "only 250,000" NOK (roughly $£ 23,000$ ). Nonetheless, even with a debt she perceives as relatively small, we can see that at a point she experienced it as impossible to relate to, along with a feeling of being pursued by creditors and having no answer for them. A number of probation caseworkers mentioned this unmanageable pile of bills, also noting debt often receives only passing mention and/or that they must push their clients to reflect and take action:

...there is the thing with the letter-phobia, that when you come out [of prison] and begin to sort out all these things that have been, heh, laborious and tiresome, for many that is like a big shock. So they don't sort it out and so suddenly they get a [salary or benefits] deduction or something else happens.

Thirty percent of prisoners surveyed in 2014 reported literacy problems (Revold 2015), so this fear of letters stems not merely from their content. One caseworker described how the welfare agency continued to communicate via letter and SMS despite being informed of a client's illiteracy. The quote above sets dealing with debt in the context of the other challenges faced by those exiting prison and seeking to turn their lives around. The letter-phobia is an extra difficulty to add to the insecure and often painful (Nugent and Schinkel 2016) process of desisting from crime. Another caseworker brings these issues together, noting the limited active engagement with debt within the criminal care system until the Red Cross debt project began.

Navigating the complex bureaucracy of debt is a difficult and time-consuming task, and even probation caseworkers have sometimes shied away from it:

$\mathrm{CW}$ : I guess I have always thought it was a major barrier really, but it has been a bit like an insurmountable obstacle to begin to work with. Because I have like thought that no, this problem is so vast that I don't have the ability or time to deal with it. But then I went on a course and was told that every little thing you can do in relation to it, just to motivate to pick up the envelopes, to sort them, to find out where the debt comes from. Even these things, to start there, then you have done a great job already. Because it's there that just about everyone has to start. [...] So now I ask a lot more and offer to help in getting an oversight and opening envelopes for example. Because I understand that this is an enormous step for very many to take.

$\mathrm{J}$ : Yeah, absolutely. And how is that for them? 
CW: Yeah, right? So, if I think like... When $I$ thought like that as a caseworker, how big of a barrier must it have been for them? [...] So now debt has become a really important topic and being able to get an oversight and signal that there is a possibility to work towards a future that is not saddled with debt. And how important it is for people, I don't think I had really appreciated that before now.

This account reinforces why potential desisters are often afraid not only of the letters and chasing telephone calls, but also of trying to start getting an overview of the problem. This sense of being overwhelmed, both by the scale of the problem and the wave of letters and phone calls, is likely to erode the sense of self-efficacy and agency that has been widely acknowledged as important in meeting the challenges presented by desistance in constrained structural contexts (see for example Healy 2013; King 2012; Maruna 2001; van Ginneken 2017). Andvig et al. (2019) also describe interviewees experiencing debt as paralysing and as pushing them towards drug use. Help is important for handling the practicalities of getting oversight, for navigating the debt bureaucracy, and for moral support and encouragement. This speaks to the relational nature of desistance (Weaver 2015) and the positive potential of a constructive relationship between client and caseworker (Farrall et al. 2014). Probation supervision that is experienced as helpful can avert the stigmatising, maloptic experience of being unfairly controlled and surveiled (McNeill 2018b). This shows how parallel practices and interventions (maloptic or otherwise) by the state can both help and hinder desistance. For the desister, even taking these piles of bills and sorting them into stacks for each creditor can give a small feeling of agency and progress: tiny victories like this can stave off the derailment of a nascent desistance process. An informant who had recently achieved a debt settlement described how the Network House helped him get started:

Benjamin: ...just getting an oversight and feedback that this here, it is possible to find a solution and it is possible to do something with it. That was really good to hear, at the same time there is a lot of shame, but it wasn't rubbed in... Instead you rather turn it around and say "there are possibilities to sort it out". That was very positive.

Benjamin was not the only one to mention a feeling of shame regarding debt. Admitting to something shameful and exposing vulnerability - often construed as 'weakness' (Layton 2018: 19) — is an additional barrier to getting started in dealing with debt. The caseworker quoted above described a particular example:

When he came to meet me for the first time after release he said he had two bags full of envelopes sitting in a cupboard. So we talked a bit about it and next time he said "Kate, now I have opened all the envelopes and put them in a stack". Just doing this was a big thing for him and now he has sorted them all, even contacted the creditors just to check if he owes them money and how much. So it is a beginning, though in view of the fact that he has a lot of debt I don't think it'll be anything other than a debt settlement for him in one way or another.

This story is double-edged, in that whilst making a start on dealing with debt was an important step for the client, ultimately there is no other sustainable solution than seeking a debt settlement. Those who have significant debt and who want to move away from crime have therefore an extra burden of getting started with a demanding and extended process of repayment. It is no wonder many fear even starting to open envelopes or answer the phone. 


\subsection{Unfairness and double punishment}

Being sentenced to both imprisonment and an economic sanction was viewed as unfair and as a form of double punishment by both desisters and probation caseworkers. This chimes with the experiences of Danish ex-prisoners interviewed by Olesen $(2016,2017)$. The notion of double punishment is important because it speaks to an experience of pervasive punishment; while debts remain unpaid, the feeling of being punished endures. Regarding unfairness, Tyler and Blader (2003: 353 ) note that procedural justice is important because people engage in identity development on the basis of information received from those around them, in particular evaluations of procedural fairness (see also Wittouck and Vander Beken, 2019). Applying their argument to desistance, an experience of being treated fairly by society will help secure the process of identity change. Conversely, the sense of unfairness created by debt is unhelpful for desistance because it hinders this shift to a more pro-social identity. As one informant argued:

Casper: Of course you have all these challenges, how can you tell a guy that okay you're coming out and you have over 1 million debt and then you sit as I sit eight years and then... You're going to live normal? Because you're not, because you have to work and then they take all your money from you basically. [...] This is the way I think they're trying to get us to do... go back again. I feel. It's a double sentence.

$\mathrm{J}$ : Yeah, it's not a clean slate when you come out.

Casper: Because you always... You're already caught for the money you, the money that you... they can say you earned, this is why sitting in jail. So you... and at the same time you're paying back when you come out again. I thought all this, the years you've lost was because of this money. [...] So it's also, I see that people they become like: "Ah, I don't care about this". And then they start doing crime because they say: "I don't have a chance anyway".

Casper contrasts how he feels society expects him to live normally and get a job, but treats him abnormally (and unfairly) by taking all his money. As a result, he experiences the system ('they') attempting to drive him back into crime by imposing 'a double sentence'. Probation caseworkers also mentioned double punishment:

So it is like, you get a sentence, but you get a sort of double punishment. You get a prison sentence and you get an economic punishment as well, which is to say the least not very rehabilitative.

I think it ends up as a kind of extra punishment all in all, when they are sentenced to pay but they don't have the funds or ability to pay. So it then hangs over them and becomes then a vicious circle.

As another caseworker observed, this is even worse in cases where two or more people are held solidarily responsible. Here all debtors are held responsible for the entire claim until it is paid in full. So even if one of three solidary debtors pays off one third of the owed amount, he/she remains equally responsible for the remaining two thirds (Statens innkrevingssentral 2014):

CW: ...you have these solidary fines as well, where two, three, four, five people have to share a fine and it must be paid. And the bailiff or the state, they don't care who it is that pays. But none of them get away from it before it is paid. So if four of them 
don't give a damn and the fifth pays, then it is the fifth that then gets the debt. So it is a solidary debt that is horribly without solidarity.

J: Yeah, huh.

CW: Yeah, gruesome debt to get. You can't get away from it and it feels incredibly unfair. And I think that it must, it becomes very... I don't know, prejudicial or something, my opinion is that it is nasty. The few cases I have been involved in where we have it, well it... it stirs up the feeling of being unfairly treated.

These, admittedly more seldom, cases of solidary debt invoke even stronger feelings of unfairness, particularly if not all those responsible take an interest in dealing with the debt. A feeling of being held back, by both the system and one's erstwhile colleagues, is doubly frustrating. Weaver and McNeill (2015) have underlined the importance of reciprocity as generating and regenerating bonds within social relationships; solidary debt of this kind has the potential to severely undermine social bonds through a lack of reciprocity and the production of 'relational bads' like fear and mistrust. Even if someone was to demonstrate agency and pay off what they might see as 'their share' of a solidary debt, they continue to be positioned by the state as equal in status to those who have not taken any responsibility. This seems in many ways the antithesis of solidarity. The experience of undermined reciprocity also applies more broadly: the perception of double punishment and unfair treatment may well weaken bonds to 'normal society' and perpetuate an experience of liminality. The experience of double punishment also shows that, in addition to the penal-welfare oriented punishment delivered by the Norwegian Correctional Services, a more retributive and less welfare-oriented penality can be observed gripping those with 'punishment debt' even after their sentence is served.

\subsection{Why bother working?}

Research on ex-prisoners in Norway shows people in employment are less likely to be re-incarcerated (Aaltonen et al. 2017; Skardhamar and Telle 2009, 2012), albeit that most stop committing crime prior to the transition into employment (Skardhamar and Savolainen 2014). Employment is best seen then as something that helps desistance bed in, rather than as an initiator. In any case, employment is important for many desisters as a source of income, meaning and new pro-social relationships. For many potential desisters in Norway, being in debt reduces the motivation to find employment (similar to indebted ex-prisoners in Denmark (Olesen 2017)). Salary deductions by SISMO leave debtors with a minimum monthly subsistence. Whilst generous compared to welfare payments in many other countries, these rates are approximately equivalent to welfare benefits in Norway. This has implications for motivation in seeking and/or maintaining employment. Moreover, whilst researchers tend to look to international comparison, those living on this minimum subsistence are more likely to compare themselves to Norway's affluent society more broadly and thereby experience relative deprivation (Eibner and Evans 2005). This matters because even in Norway relative deprivation is associated with increased mortality (Elstad et al. 2006), poorer health outcomes (Huijts et al. 2010) and childhood mental health problems (Gunnarsdóttir et al. 2016). One caseworker describes a client released after 11 years in prison with 7 million NOK $(£ 650,000)$ of debt:

You're in a way not done with your sentence, when you come here and you also have seven million in debt and you're going to start working but you know you'll never 
have money really, because everything is taken. And seven million, that's really, it's a massive amount of money! [...] So you serve 11 years and come out and it hangs over you. You are in a way not done with it. So I completely understand that, what is the point of finding a job when you... when it's not going to help at all?

The caseworker described how this client had exited prison motivated to complete his education and get a good job, but that this motivation ebbed away. The caseworker explained that the prospect of having to live on the state's minimum subsistence for the rest of his life, the inability to go on holiday, own a house or help his children financially meant he began to feel 'why bother at all?' So, debt here appears to be undermining what otherwise might have been a promising reintegration process. The story is also a demonstration of the material side to generativity, more often described in symbolic terms like fulfilment, exoneration and legitimacy (Maruna 2001: 118). Here generativity is constrained by lack of economic capital and thus an inability to help one's children financially. In addition, the potential for developing new, prosocial relationships in the workplace and the recognition of change this may bring (McNeill 2016) is also undermined. Another probation office spoke similarly about those released from prison with large amounts of debt:

They will maybe never have their finances in order; they will never get rid of their debt problems. [...] That of course doesn't help to increase motivation in any way to get an education and get a job. You see that you will have these creditors hanging around your neck anyway. So maybe it's one of those... the surest way to make sure somebody stays involved in crime.

Even if a desister gets a job, the practical, monetary benefits of employment are undermined though salary deductions. In addition, the symbolic aspect of employment may also be negatively affected, because the state is signalling that desisters must continue to face consequences of their criminal conviction through salary deductions: even if colleagues see you as a useful part of the team, your payslip and bank balance continue to mark you out as different.

Despite all this, informants remained keen to find/maintain employment even with significant debt. For them, even if the financial benefits might not be realised, employment was nonetheless important for having something meaningful to do. One informant described positively both the responsibility he had been given and the way he was met by colleagues on a work placement. So, whilst the signalling effect of debt is in many cases unhelpful, the tangible relationships and meaning-making experienced through employment remain valuable. The debt project has encouraged people to find/maintain employment on this basis. Forming positive, tangible relationships can help ameliorate the maloptic tendencies of debt surveillance and enforcement.

\subsection{Inescapability}

Both probation officers and desisters repeatedly highlighted a feeling that debt was inescapable. One informant described being unable to purchase a flat or take out a loan and as such a feeling of being stuck in the same spot. This feeling of thwarted progress is hardly helpful. Another informant described wishing she could get rid of the debt that was hindering attempts to start again: 
Dina: Yeah, the problem is that I still have that debt. It is, you know, I have maybe around 500,000 in debt. And it sucks, it really sucks. So I constantly have this feeling of being poor [...] Eh, it sucks so much to think, like, I have three kids I want to see more and all that. I want to get a bigger flat and everything [so that her kids can stay over]. I wish I could get rid of my debt "snap" if you get what I mean!

$\mathrm{J}$ : Yeah, sure.

Dina: Yeah, that would be great, just like when you are ready, because I am ready to like start my life again in a way. It is late in life, I'll be 50 soon. But you know I do have a few years left, I just wish I didn't have to use so many of them to sort these things out. But it takes time.

This interview excerpt shows how debt is frustrating Dina's attempt to start again by hindering her reconnection with family, a continuing experience of feeling poor and the dispiriting knowledge it takes a long time to make progress. Both the debt project leader and a probation caseworker used circular analogies to get across this feeling of inescapability:

Project leader: So you are stuck in an eternal circle of drugs and crime. And I know that some judges have even said in court that they know that the claims they impose will in all probability never be paid. So this is a kind of symbolic activity. [...] The money never arrives, but the psychological effect of the claim endures and that can be enough. Even if it has no practical economic consequences, the psychological effect can be enough that they never get out.

$\mathrm{CW}$ : Sometimes I think that these compensation demands are a bit... they don't make sense really. In that, it becomes very much a double punishment. Because you get punished, one thing is that you go to prison for it, and so in addition you get compensation debt or a demand that they know you can't pay anytime soon. One thing is to say you have a 200,000 compensation claim against you because of this. And the 200,000 just stay there until you are able to pay them down. But you are accruing interest so it becomes 300,000 and then 400,000 and maybe a million before you can really do anything about it. So they never get out of it. It is just a downward spiral that goes round and round and round.

When we think about desistance as a process that, if not having a clearly defined start and end point, then at least has a direction of travel, these notions of an eternal circle or downward spiral encapsulate debt's negative impact. As these excerpts show, debt's impact can be as much psychological and symbolic as practical. Maloptic policies and practices carry significant symbolic power. Van Ginneken (2017) has observed financial stressors and repeated use of self-control can reduce a person's capacity for further use of self-control and, by extension, agency. Her argument that "[d] ue to the mental tax of financial and other problems, offenders may struggle to resist immediate temptations to earn easy money (illegally) or forget briefly about stress through substance abuse" (p. 249) seems apposite here. Desistance demands significant agentic effort, and being in debt has the pernicious double impact of increasing these agentic demands whilst further constraining the desister's structural position over the long term. 


\section{Concluding Discussion}

This article has shown how 'punishment debt' is accrued, surveilled and enforced in Norway, and how such debt impedes reintegration and desistance from crime. Efforts aimed at rehabilitation and resocialisation risk being undermined by attempts to enforce this debt. As it stands, Norwegian law, jurisprudence and administrative practice regarding fines, compensation and confiscation work against the reintegratory efforts of the criminal care system and indeed the efforts of desisters themselves. They risk being trapped in the malopticon of debt surveillance and enforcement, being seen badly (as debt repayment objects), being seen as bad (unentitled to own assets or earn more than a minimum subsistence) and being projected and represented as bad (leading to feeling unfairly treated, demotivated and trapped). Large and persistent debt to the Norwegian state may well mean desisting to a form of frozen liminality, living on a state-defined minimum subsistence for indeterminate time.

We can also draw implications for desistance research more broadly. Regarding primary desistance, if we consider that for each desister there is a period where derailment is at greater risk, debt both increases the risk of derailment and, where debt is large and persistent, extends this period through long-term debt enforcement. Debt also affects secondary and tertiary desistance, in that it is difficult to develop a new, pro-social identity while being reminded of one's past with every payment demand or garnished payslip. The struggle to keep one's head above water financially will reinforce and prolong the liminal experience of desisting from crime. As such, this article is a further demonstration of how desistance involves interconnection between the material, the psychological and the symbolic. Take generativity, which is often described in symbolic or psychological terms, but here its material aspect is brought into focus. An inability to help one's family financially or afford living space that enables contact with them limits opportunity to experience generativity, whilst also increasing feelings of relative deprivation. Research on understanding how debt influences the interconnected aspects of desistance in different contexts would therefore be useful, and indeed regarding to what extent debt is experienced as punitive.

The findings also have implications for research on penal exceptionalism, both in terms of how this research agenda is taken forward and how we characterize penality in Norway. I have sought to demonstrate the benefits of broadening the penal exceptionalism research agenda both horizontally beyond the prison gates and vertically to capture more of the lived experience of punishment. This broadening has made visible a previously unseen aspect of Norwegian penality and shown that punishment there is more pervasive than previously thought. Moreover, whilst it has been established that Scandinavian and Nordic states have the ability and will to intervene significantly in the lives of their polities, the findings here reinforce the importance of avoiding monolithic understandings of these states. Different and sometimes discordant practices and policies employed by different parts of the state play out across people's lives in diverse ways. As such, we must take a broad perspective that enables us to see the full impact (punitive or otherwise) of these diverse practices and policies.

There are also implications to consider for how we think about punishment and its legitimacy, particularly given debt can create an experience of double punishment and 
prolong the experience of being punished. Debt impacts punishment's internal (i.e. amongst those subjected to it - see Bottoms 2003: 186) legitimacy in both respects. As McNeill (2019: 132-3) has recently observed, punishment that pervades to the extent of being experienced as unending and inescapable is less likely to be experienced as legitimate. And given that Bottoms and Tankebe (2012) describe legitimacy as dialogic, developed relationally between power-holders and audiences (or punisher and punished), the legitimacy problems created by debt-as-punishment will likely affect the broader relationship between individuals and the power-holder that they see as treating them unfairly. It is therefore important that we take debt seriously as a penological and criminological issue that has significant symbolic as well as practical exclusionary impact.

Notes

${ }^{1}$ Gwen Robinson (2016) makes a similar point regarding punishment and society research more broadly.

${ }^{2}$ Bottoms and Shapland (2011:61) also note the most common perceived obstacle for Sheffield Desistance Study participants was lack of money.

${ }^{3}$ In addition to compensation awarded via the Criminal Injuries Compensation Authority, the court may order payment of compensation and/or costs, but payments tend to be smaller and based on ability to pay (Sentencing Council, n.d.; The Crown Prosecution Service 2018).

\section{References}

Aaltonen, Mikko, Oksanen, Atte, and Kivivuori, Janne (2016), 'Debt problems and crime', Criminology, 54 (2), 307-31.

Aaltonen, Mikko, et al. (2017), 'Comparing Employment Trajectories before and after First Imprisonment in Four Nordic Countries', The British Journal of Criminology, 57 (4), 828-47.

Aas, Katja Franko (2014), 'Bordered penality: Precarious membership and abnormal justice', Punishment \& Society, 16 (5), 520-41.

Amundsen, Marie-Lisbet (2006), 'Innsatte og psykisk helse', Nordisk Tidsskrift for Kriminalvidenskab, 93 (2), 181-92.

Anderson, Yanique A and Gröning, Linda (2017), 'Rehabilitation in Principle and Practice: Perspectives of Inmates and Officers', Bergen Journal of Criminal Law \& Criminal Justice, 4 (2), 220-46.

Andvig, E., Bjørlykhaug, K. I., and Hummelvoll, J. K (2019), 'Victims of debt after imprisonment: Experiences of Norwegians with substance use challenges', Scandinavian Psychologist, 6 (1).

Bannon, Alicia, Nagrecha, Mitali, and Diller, Rebekah (2010), Criminal justice debt: a barrier to reentry (Brennan Center for Justice at New York University School of Law New York).

Bottoms, Anthony (2003), 'Theoretical reflections on the evaluation of a penal policy initiative', in Lucia Zedner and Andrew Ashworth (eds.), The criminological 
foundations of penal policy: Essays in honor of Roger Hood (Oxford: Oxford University Press), 107-94

Bottoms, Anthony and Shapland, Joanna (2011), 'Steps towards desistance among male young adult recidivists', in Stephen Farrall, et al. (eds.), Escape routes: Contemporary perspectives on life after punishment (Abingdon, New York: Routledge), 43-80.

Bottoms, Anthony and Tankebe, Justice (2012), 'Beyond procedural justice: A dialogic approach to legitimacy in criminal justice', The journal of criminal law and criminology, 119-70.

Boyesen, Britt (2018), 'Slipper aldri unna - må betale 34 millioner', (updated 2.12.2017) <https://www.nrk.no/telemark/domt-til-a-betale-34-millionerkroner-1.13800764>, accessed 6 July.

Cavadino, Michael and Dignan, James (2005), Penal systems: A comparative approach (London, Thousand Oaks: Sage).

Clayton, Maya, Liñares-Zegarra, José, and Wilson, John OS (2015), 'Does debt affect health? Cross country evidence on the debt-health nexus', Social science \& medicine, 130, 51-58.

Departementene (2017), 'Redusert tilbakefall til ny kriminalitet: Nasjonal strategi for samordnet tilbakeføring etter gjennomført straff 2017-2021'.

Dyb, Evelyn, et al. (2006), 'Løslatt og hjemløs', (Norsk institutt for by-og regionforskning).

Eibner, Christine and Evans, William N. (2005), 'Relative Deprivation, Poor Health Habits, and Mortality', Journal of Human Resources, XL (3), 591-620.

Elstad, Jon Ivar, Dahl, Espen, and Hofoss, Dag (2006), 'Associations between relative income and mortality in Norway: a register-based study', European Journal of Public Health, 16 (6), 640-44.

Eriksrud, Guro Sollien (2016), 'GJELDSARBEID: Få oversikt - finn løsninger', (Røde Kors Nettverk etter soning).

Evans, Douglas (2014), 'The debt penalty: Exposing the financial barriers to offender reintegration', (New York: Research \& Evaluation Center, John Jay College of Criminal Justice, City University of New York).

Farrall, Stephen, et al. (2014), Criminal careers in transition: The social context of desistance from crime.

Giordano, Peggy C, Cernkovich, Stephen A, and Rudolph, Jennifer L (2002), 'Gender, Crime, and Desistance: Toward a Theory of Cognitive Transformation1', American Journal of Sociology, 107 (4), 990-1064.

Gjeldsordningsloven (1992), 'Lov om frivillig og tvungen gjeldsordning for privatpersoner', (LOV-1992-07-17-99; Norway).

Gunnarsdóttir, Hrafnhildur, et al. (2016), 'Relative deprivation in the Nordic countries - child mental health problems in relation to parental financial stress', European Journal of Public Health, 26 (2), 277-82.

Halsey, Mark, Armstrong, Ruth, and Wright, Serena (2016), 'FF* ck It!': Matza and the Mood of Fatalism in the Desistance Process', British Journal of Criminology, 57 (5), 1041-60.

Hansen, Inger Lise Skog (2017), 'NAV i fengsel: En følgeevaluering av innsattes tilgang til NAV-tjenester', Fafo-rapport 2017 (37).

Harris, Alexes, Evans, Heather and Beckett, Heather (2010), 'Drawing Blood from Stones: Legal Debt and Social Inequality in the Contemporary United States', American Journal of Sociology, 115 (6), 1753-99. 
Healy, Deirdre (2010), The dynamics of desistance: Charting pathways through change (London: Willan) 240.

--- (2013), 'Changing fate? Agency and the desistance process', Theoretical Criminology, 17 (4), 557-74.

Huijts, Tim, Eikemo, Terje Andreas, and Skalická, Vera (2010), 'Income-related health inequalities in the Nordic countries: Examining the role of education, occupational class, and age', Social Science \& Medicine, 71 (11), 1964-72.

Iversen, Mats Jonatan Stenmark (2008), 'Beviskravsregelen i straffeloven § 34a andre ledd', Tidsskrift for strafferett, 8 (04), 379-411.

Jenkins, Rachel, et al. (2008), 'Debt, income and mental disorder in the general population', Psychological medicine, 38 (10), 1485-93.

Johnsen, Jon T. (2001), 'Bør retten kunne ilegge en tiltalt erstatning selv om den frikjenner ham for straff?', Tidsskrift for strafferett, 1 (02), 98-101.

Justis- og Politidepartement (2008), 'Straff som virker: mindre kriminalitet - tryggere samfunn', in Justis- og Politidepartementet (ed.), (Kriminalomsorgsmelding).

King, Sam (2012), 'Transformative agency and desistance from crime', Criminology and criminal justice, 13 (3), 317-35.

Kontoret for Voldsoffererstatning (2014), 'Statlig erstatning til personer utsatt for vold og overgrep', (Vardø).

--- (2018), 'Vilkår for voldsoffererstatning', $<$ https://www.voldsoffererstatning.no/vilkaar-forvoldsoffererstatning.478949.no.html>, accessed 8 March.

--- (n.d.), 'Regress', <http://www.voldsoffererstatning.no/informasjon-omregress.326998.no.html>, accessed 4 July.

Layton, Lynne (2018), 'Relational thinking: from culture to couch and couch to culture', in Simon Clarke, Herbert Hahn, and Paul Hoggett (eds.), Object relations and social relations (Routledge), 1-24.

Levingston, Kirsten D. and Turetsky, Vicki (2007), 'Debtors' Prison - Prisoners' Accumulation of Debt as a Barrier to Reentry', Clearinghouse Review, 41, 187-97.

Martire, Kristy, et al. (2011), 'Financial sanctions and the justice system: Fine debts among New South Wales prisoners with a history of problematic substance use', Australian \& New Zealand Journal of Criminology, 44 (2), 258-71.

Maruna, Shadd (2001), Making good : how ex-convicts reform and rebuild their lives (Washington, D.C.: American Psychological Association) xix, 209 p.

--- (2011), 'Reentry as a rite of passage', Punishment \& Society, 13 (1), 3-28.

Maruna, Shadd, et al. (2004), 'Pygmalion in the reintegration process: Desistance from crime through the looking glass', Psychology, Crime \& Law, 10 (3), 27181.

McNeill, Fergus (2016), 'Desistance and criminal justice in Scotland', in Hazel Croall, Gerry Mooney, and Mary Munro (eds.), Crime, justice and society in Scotland (Abingdon: Routledge), 200-15.

--- (2018a), 'Mass supervision, misrecognition and the 'Malopticon', Punishment \& Society, $0(0), 1462474518755137$.

--- (2018b), '“Academic changes mind!"' (But only his own...)', in Fergus McNeill (ed.), Pervasive Punishment (2018).

--- (2019), Pervasive Punishment: Making Sense of Mass Supervision (Bingley: Emerald Publishing).

McNeill, Fergus and Maruna, Shadd (2007), 'Giving up and giving back: Desistance, generativity and social work with offenders', in Gill McIvor and Peter Raynor 
(eds.), Developments in social work with offenders (London, Philadelphia: Jessica Kingsley Publishers), 224-339.

McNeill, Fergus, et. al. (2012), 'How and why people stop offending: discovering desistance. ' Insights evidence summary to support social services in Scotland.

Miers, David (2014), 'Offender and state compensation for victims of crime: Two decades of development and change', International Review of Victimology, 20 (1), 145-68.

Ministry of Justice (2012), 'The Criminal Injuries Compensation Scheme 2012', in Ministry of Justice (ed.), (London: The Stationery Office).

Norwegian Ministry of Justice and the Police (2008), 'Punishment that works - less crime - a safer society: Report to the Storting on the Norwegian Correctional Services'.

Nugent, Briege and Schinkel, Marguerite (2016), 'The pains of desistance', Criminology \& Criminal Justice, 16 (5), 568-84.

O’Malley, Pat (2011), 'The Currency of Freedom?', Social \& Legal Studies, 20 (4), 546-56.

Olesen, Annette (2013), Løsladt og gceldsat (Jurist-og Økonomforbundet).

--- (2016), 'Debt as a Criminal Risk Factor in Denmark', Oñati Socio-Legal Series, 6 (3), 676-706.

--- (2017), 'Released to the "battlefield" of the Danish welfare state: A battle between support and personal responsibility', Scandinavian penal history, culture and prison practice (Springer), 271-95.

Olesen, Annette and Storgaard, Anette (2016), 'Released from Prison in Denmark: Experiences vs. Ambitions', Parole and Beyond (Springer), 49-76.

Phelps, Michelle S (2017), 'Mass probation: Toward a more robust theory of state variation in punishment', Punishment \& Society, 19 (1), 53-73.

Pratt, John (2008a), 'Scandinavian exceptionalism in an era of penal excess part I: The nature and roots of scandinavian exceptionalism', British Journal of Criminology, 48 (2), 119-37.

--- (2008b), 'Scandinavian Exceptionalism in an Era of Penal Excess: Part II: Does Scandinavian Exceptionalism Have a Future?', British Journal of Criminology, 48 (3), 275-92.

Reiter, Keramet, Sexton, Lori, and Sumner, Jennifer (2018), 'Theoretical and empirical limits of Scandinavian Exceptionalism: Isolation and normalization in Danish prisons', Punishment \& Society, 20 (1), 92-112.

Revold, Mathias Killengreen (2015), 'Innsattes levekår 2014: Før, under og etter soning', (47; Oslo, Kongsvinger: Statistisk Sentralbyrå).

Rex, Sue (1999), 'Desistance from offending: Experiences of probation', The Howard Journal of Criminal Justice, 38 (4), 366-83.

Richards, Stephen C and Jones, Richard S (2004), 'Beating the perpetual incarceration machine: Overcoming structural impediments to re-entry', in Shadd Maruna and Russ Immarigeon (eds.), After crime and punishment: Pathways to offender reintegration (Cullompton: Willan), 201-32.

Richardson, Thomas, Elliott, Peter, and Roberts, Ronald (2013), 'The relationship between personal unsecured debt and mental and physical health: A systematic review and meta-analysis', Clinical Psychology Review, 33 (8), 1148-62.

Robinson, Gwen (2016), 'The Cinderella complex: Punishment, society and community sanctions', Punishment \& Society, 18 (1), 95-112. 
Sampson, Robert J and Laub, John H (1997), 'A life-course theory of cumulative disadvantage and the stability of delinquency', Developmental theories of crime and delinquency, 7, 133-61.

Selenko, Eva and Batinic, Bernad (2011), 'Beyond debt. A moderator analysis of the relationship between perceived financial strain and mental health', Social science \& medicine, 73 (12), 1725-32.

Sentencing Council (2018), 'Introduction to compensation', Explanatory materials $<\mathrm{https}$ ://www.sentencingcouncil.org.uk/explanatory-material/item/fines-andfinancial-orders/compensation/1-introduction-to-compensation/>, accessed 8 August.

Shammas, Victor L (2017), 'Prisons of Labor: Social Democracy and the Triple Transformation of the Politics of Punishment in Norway, 1900-2014', in Peter Scharff Smith and Thomas Ugelvik (eds.), Scandinavian Penal History, Culture and Prison Practice (London: Palgrave Macmillan), 57-80.

Shapland, Joanna, et al. (2012), The quality of probation supervision-a literature review (University of Sheffield. Centre for Criminological Research).

Skardhamar, Torbjørn and Telle, Kjetil (2009), 'Life after prison: The relationship between employment and re-incarceration', Discussion Papers (597; Oslo, Kongsvinger: Statistics Norway).

--- (2012), 'Post-release employment and recidivism in Norway', Journal of Quantitative Criminology, 28 (4), 629-49.

Skardhamar, Torbjørn and Savolainen, Jukka (2014), 'Changes in criminal offending around the time of job entry: a study of employment and desistance', Criminology, 52 (2), 263-91.

Skatteetaten (2018), 'Årsrapport 2017 for Skatteetaten', 80.

Smith, Jonathan and Osborn, Mike (2007), 'Interpretative phenomenological analysis', in: Jonathan Smith (ed.), Qualitative Psychology: A Practical Guide to Research Methods. (London: Sage), 53-80.

Smith, Peter Scharff and Ugelvik, Thomas (2017a), Scandinavian Penal History, Culture and Prison Practice: Embraced by the Welfare State? (Palgrave Studies in Prisons and Penology; London: Palgrave Macmillan).

--- (2017b), 'Punishment and Welfare in Scandinavia', in Peter Scharff Smith and Thomas Ugelvik (eds.), Scandinavian Penal History, Culture and Prison Practice (Palgrave Studies in Prisons and Penology; London: Palgrave), 51130.

Statens innkrevingssentral (2014), 'Solidarinnkreving - når flere er ansvarlig for samme krav', (updated 17.07.2014)

$<$ https://www.sismo.no/no/pub/tema/solidarinnkreving $>$, accessed 6 July.

--- (2018), 'Hva hvis den som skal betale erstatningen ikke har penger nå?', (updated 10.09.2018)

$<$ https://www.sismo.no/no/pub/tjenester/informasjon_erstatning_tjeneste/ersta tningspliktig_har_ikke_penger_naa $>$, accessed 6 July.

Statistics Norway (2018a), 'General government revenue and expenditure', Statbank $<$ https://www.ssb.no/en/statbank/table/10721/tableViewLayout1/>, accessed 4 November.

--- (2018b), 'Sanctions', Social conditions, welfare and crime (updated 27 September 2018) $<\mathrm{https}$ ://www.ssb.no/en/sosiale-forhold-ogkriminalitet/statistikker/straff $>$, accessed 19 October.

Svendsen, Eileen and Lorange, Eva (2018), 'Nettverk etter soning i Oslo', $<$ https://www.rodekors.no/om-rode-kors/lokalforeninger-og- 
distrikter/oslo/aktiviteter/under-og-etter-fengselsopphold-i-oslo/nettverk-ettersoning-i-oslo/>, accessed 13 July.

Sweet, Elizabeth, et al. (2013), 'The high price of debt: Household financial debt and its impact on mental and physical health', Social Science \& Medicine, 91, 94100.

The Crown Prosecution Service (2018), 'Costs', Legal Guidance (updated 12 February 2018) <https://www.cps.gov.uk/legal-guidance/costs>, accessed 8 August.

Trotter, Chris and Sheehan, Rosemary (2017), 'Women in the justice system: Maintaining desistance', Women's Transitions from Prison (Routledge), 12326.

Turner, Victor (1969/2008), 'Liminality and communitas', The ritual process (New Brunswick, London: Aldine Transaction), 94-113.

Tyler, Tom R. and Blader, Steven L. (2003), 'The Group Engagement Model: Procedural Justice, Social Identity, and Cooperative Behavior', Personality and Social Psychology Review, 7 (4), 349-61.

Ugelvik, Thomas (2012), 'The dark side of a culture of equality: Reimagining communities in a Norwegian remand prison', in Thomas Ugelvik and Jane Dullum (eds.), Penal Exceptionalism? Nordic Prison Policy and Practice (London: Routledge).

Ugelvik, Thomas and Damsa, Dorina (2017), 'The Pains of Crimmigration Imprisonment: Perspectives From a Norwegian All-foreign Prison', British Journal of Criminology, 58 (5), 1025-43.

van Ginneken, Esther FJC (2017), 'Constrained agency: The role of self-control in the process of desistance', in Emily Luise Hart and Esther F.J.C. van Ginneken (eds.), New Perspectives on Desistance (Springer), 241-65.

Weaver, Beth (2015), Offending and Desistance: The Importance of Social Relations (Routledge).

Weaver, Beth and McNeill, Fergus (2015), 'Lifelines:Desistance, Social Relations, and Reciprocity', Criminal Justice and Behavior, 42 (1), 95-107.

Wittouck, Ciska and Vander Beken, Tom (2019), 'Recovery, desistance, and the role of procedural justice in working alliances with mentally ill offenders: a critical review', Addiction Research \& Theory, 1-13. 